\title{
Конструирование образа антиалкогольной политики России в новостных медиа: риторика преодоления пьянства и контрриторические стратегии
}

\author{
Ю.Ю. БЕЛОВА*
}

\begin{abstract}
*Юлия Юрьевна Белова - кандидат социологических наук, научный сотрудник, Лаборатория экономико-социологических исследований, Национальный исследовательский университет «Высшая школа экономики». Адрес: 101000, Москва, ул. Мясницкая, д. 11. E-mail: ybelova@hse.ru
\end{abstract}

Цитирование: Белова Ю.Ю. (2019) Конструирование образа антиалкогольной политики России в новостных медиа: риторика преодоления пьянства и контрриторические стратегии // Мир России. Т. 28. № 3. С. 155-175. DOI: 10.17323/1811-038X-2019-28-3-155-175

В статье с позищий социального конструкционизма анализируются особенности создания новостными медиа образа антиалкогольной политики России. Тема исследования разворачивается от анализа риторики преодоления тяжелого пьянства как узкого аспекта алкоголизачии населения к поиску стратегий контрриторики, связанных с антиалкогольными мерами государства. На основе результатов количественного $(N=37903)$ и качественного $(N=10002)$ контент-анализа тематических сообщений новостных медиа и их заголовков за 2016-2017 г2., произведенного с помощью информаџионно-аналитической системь «Медиалогия», построена авторская типология контрриторических стратегий в отношении антиалкогольной политики. Типология включает стратегии: 1) иронизации, связанной с высмеиванием мер преодоления алкоголизации населения, 2) вульгаризаџии, направленной на упрощение и искажение их смысла, 3) советизации, способствующей формированию ассочиативных связей современной антиалкогольной политики с горбачевской антиалкогольной кампанией, 4) мифологизации, культивирующей вымышленные представления об эффективности антиалкогольной политики, 5) гиперболизации, эксплуатирующей преувеличенные суждения о ней, 6) десакрализации, обесиенивающей ее смысль, и 7) патологизации, придающей сомнительность адекватности реализации антиалкогольных мер.

Среди результатов исследования следует выделить анализ лейтмотивов сообщений новостных медиа и контрриторических стратегий, произведенный с помощью методологии П. Ибарры и Дю. Китсьюза. Сделан вывод, что используемая в СМИ контрритори-

1 Исследование выполнено при финансовой поддержке гранта Президента Российской Федерации для государственной поддержки молодых российских ученых - кандидатов наук (проект МК-6274.2018.6). 
ка создает отчуждаюший и даже катастрофический образ антиалкогольной политики. Результать исследования свидетельствуют о наличии противоречия между риторикой преодоления тяжелого пьянства рестриктивными мерами и отчуждающим образом рестриктивной антиалкогольной политики государства. Основным выводом является то, что контрриторические стратегии, драматизирующче пути решения проблемь тяжелого пьянства, формируют восприятие фатальности процесса алкоголизации населения.

Ключевые слова: конструкционизм, антиалкогольная политика, депроблематизация, алкоголизация, алкоголизм, пьянство, контрриторические стратегии

\section{Введение}

Многие явления, рассматриваемые с позиций социального конструкционизма как сконструированные социальные проблемы, прежде чем стать таковыми, сталкиваются с «избирательным процессом» и «коллективным определением» [Блумер 2007, с. 18], детерминируются деятельностью групп по выдвижению «утверждений-требований» [Спектор, Китсьюз 1998, с. 77], «признаются, идентифицируются, именуются» социальными проблемами [Бест (2) 2007, с. 27$].$ По мнению Г. Блумера, в то время как статус социальных проблем получают одни явления, другие его достичь не могут: многие примеры ужасных социальных условий так и не были замечены в истории [Блумер 2007, с. 14].

Еще до появления конструкционистской интерпретации возникновения социальных проблем П. Лазарсфельд и Р. Мертон указывали, что функцией присвоения статуса общественным проблемам обладают средства массовой коммуникации [Лазарсфельд, Мертон 2002, с. 140-141], затем роль средств массовой коммуникации в их отборе стала предметом специальных исследований конструкционистов [Бест (2) 2007, с. 29]. Механизм конструирования социальных проблем средствами массовой информации обосновывается концепцией «моральных паник» Стэнли Коэна, согласно которой при освещении тех или иных феноменов как общественных угроз преувеличивается их опасность и нагнетаются их последствия [Cohen 1973]: так, с ее помощью проводятся исследования на тему наркотизации населения и ее профилактики [Мейлахс 2004].

Важно подчеркнуть, что в противовес процессу драматизации СМИ девальвируют некоторые социальные проблемы. Э.Г. Ясавеев называет это конструированием «не-проблем», или их депроблематизацией. По его мнению, в зависимости от интереса властной элиты в обществе намеренно муссируются одни темы (например, наркомания) и игнорируются другие (например, алкоголизация) [Ясавеев 2004, с. 79-82; Ясавеев 2007, с. 256]. О.А. Матвейчев приводит пример телепередачи о наркомании, где обсуждаются две противоположные, но равноправные точки зрения - смертная казнь за употребление и распространение наркотиков и их легализация. Автор отмечает, что, на первый взгляд, это является показателем свободы СМИ, однако манипуляция заключается в том, что освещается не тема алкоголизма, а тема наркомании. Политологи это именуют формированием повестки дня: «будоражится та или иная проблема, либо она не будоражится, а, наоборот, засоряется и замуровывается» [Матвейчев 2016, с. 165-166]. 
Гипотеза настоящего исследования состоит в предположении, что алкоголизация населения как массовый мультисоциальный процесс в СМИ не столько депроблематизируется, игнорируется и «замуровывается», сколько она дифференцируется, и по поводу ее преодоления используются контрриторические стратегии. Цель исследования предполагает выявление характера контрриторики, созданной вокруг нынешней государственной антиалкогольной политики в средствах массовой информации. Нестандартность объекта исследования подчеркивается противоречивостью восприятия населением темы потребления алкоголя и антиалкогольных мер, что, несомненно, усиливает манипулятивные эффекты сообщений СМИ. Так, при существующем консенсусе относительно необходимости преодоления процесса алкоголизации на социетальном уровне (64\% россиян готовы поддержать антиалкогольную кампанию [Алкоголизм, и как с ним бороться 2017]) большинство людей допускают употребление алкоголя для себя лично (59\% [Губит людей не пиво 2017]). При этом 45\% россиян считают алкоголизм болезнью, требующей медицинского вмешательства, и лишь $27 \%$ - социальной проблемой [Алкоголизм, и как с ним бороться 2017], однако наибольшей поддержкой пользуются меры, направленные на общество в целом, а не на отдельную группу алкоголезависимых граждан: например, 53\% выступают за запрет продажи алкоголя молодежи до 21 года и т.д. [Алкоголизм, и как с ним бороться 2017]. В то же время следует отметить, что в России увеличивается доля трезвенников среди населения (до 40\% в 2018 г. [Безвредный алкоголь 2018]) и растет площадь «территорий трезвости», где люди полностью отказываются от алкоголя (по некоторым оценкам, около 1000 трезвых сел)².

\section{Дизайн исследования: логика моделирования выборки}

Для исследования выбран метод качественно-количественного контент-анализа статей новостных медиа (информагентств, газет, журналов), опубликованных за два календарных года (2016 и 2017 гг.), где алкоголепотребление упоминалось в связи с его преодолением в аспекте «мягких» и «жестких» мер антиалкогольной политики (профилактики и запрещения). Отбор ключевых слов, отражающих релевантные словосочетания и ассоциации, производился посредством интернетсервисов «Яндекс. Статистика» ${ }^{3}$ и «Сеть словесных ассоциаций» ${ }^{4}$, далее для отбора публикаций применялась автоматическая система мониторинга и анализа СМИ «Медиалогия» ${ }^{5}$. С учетом отобранных ключевых слов и при помощи логических операторов осуществлялся единый контекстный поиск для всех регионов России по следующей формуле: <профилактика, противодействие, запрет>, <алкоголизм, пьянство, алкоголь $>$. В выборку попали статьи, в которых встречались сочетания заданных слов в любом порядке и склонении (например, «профилактика

2 Елков И., Скрипка А., Таюрский В. (2018) Трезвые. В России около тысячи деревень отказались от алкоголя // Российская газета. 18 марта 2018 // https://rg.ru/2018/03/14/v-rossii-okolo-tysiachi-dereven-otkazalis-ot-alkogolia.html\#

3 https://wordstat.yandex.ru/

$4 \mathrm{https}: / /$ wordassociations.net

5 http://www.mlg.ru 
алкоголизма», «противодействие пьянству», «запрет алкоголя», «запретить алкоголь» и т.д.). Поиск осуществлялся по отраслям, близким теме исследования («бизнес и общество», «политика», «власть», «право», «образование и наука», «НКО», «религия» и т.п.). Учитывались следующие переменные: упоминаемость темы, прирост статей по упоминаемым регионам и объектам, объекты упоминаний темы (субъекты антиалкогольной политики), события, заметность событий. События, выявленные с помощью инструментов системы «Медиалогия», объединялись по тематике. Каждой группе событий присваивались соответствующие их смыслу наименования. База источников для количественного анализа составила 31488 публикаций региональных СМИ (все регионы России) и 6415 сообщений федеральных СМИ (Москва и Санкт-Петербург) (N=37903).

На следующем этапе исследования с целью определения риторических и контрриторических стратегий в отношении антиалкогольной политики производился качественный анализ заголовков статей. Заголовок является одним из наиболее значимых для восприятия элементов текста и служит инструментом привлечения внимания читателя. В.З. Демьянков показывает, как с помощью заголовков новостей производятся когнитивные манипуляции: с их помощью можно легко ввести в заблуждение и «инфицировать» подсознание читателей, которым некогда знакомиться с самим текстом [Демьянков 2017]. В этом смысле заголовки имеют потенциал для конструирования той или иной темы в целях достижения наибольшего манипулятивного эффекта.

Для анализа заголовков из полученной базы публикаций были отобраны источники (без перепечаток) по релевантным теме объектам («алкоголь» и «власть») с учетом их цитируемости. Индекс цитируемости источника рассчитывался исходя из количества ссылок на него в сторонних медиа, а также влиятельности СМИ, ссылающихся на источник 6 . Данный показатель измеряет качество распространения сообщений, что немаловажно при оценке ключевых стратегий, которые используются в отношении темы преодоления пьянства. Всего для качественного анализа заголовков были найдены 10002 статьи.

\section{Риторика преодоления тяжелого пьянства}

Риторика преодоления пьянства обосновывает ограничительную и фискальную политику государства в отношении алкоголя. Ее направленность в новостных медиа связана с интенсивными формами алкоголизации населения - тяжелым пьянством и алкоголизмом ${ }^{7}$. В свете теоретических допущений П. Ибарры и Дж. Китсьюза тяжелое пьянство можно определить как «условие-категорию», составляющую угрозу здоровью и безопасности людей. Проблематизация данной темы в СМИ осуществляется «риторикой опасности» ${ }^{8}$, а также «риторикой бед-

\footnotetext{
6 http://www.mlg.ru

7 Алкоголизм - шаг к преступлению (2016) // Новая жизнь \# Усмань. 19 января 2016; Алкоголизму объявили войну (2017) // Москва. Центр. № 14(695). 14 апреля 2017. С. 4.

8 Алкоголизм и наркомания - главные угрозы современности (2016) // ИА Грозный Информ. 11 ноября 2016 // http://www.grozny-inform.ru/news/society/78936/
} 
ствия», которая в исследуемый период связана с потреблением суррогатного алкоголя населением 9 . При этом общество разделяется на «мы» и «они», где «они» (интенсивно пьющие люди) виновны в сложившейся алкогольной ситуации ${ }^{10}$, при том что лишь незначительная часть населения (до 6\%) еженедельно употребляет алкоголь [Употребление алкоголя 2017; Губит людей не пиво 2017]. Очевидно, на нее не может приходиться все бремя, которое несет общество в результате алкоголизации населения. Однако государство в антиалкогольной политике фокусируется на группах алкоголезависимых людей, к которым применяются особые меры воздействия и надзора ${ }^{11}$. Проявляется «риторика неразумности», которая ведет к «требованиям усилить “контроль" со стороны влиятельных агентов (посредством надзора, права, осуждения или разрешения)» [Ибарра, Китсьюз 2007, с. 82], рождаются «утверждения-требования», связанные с рестриктивными мерами антиалкогольной политики ${ }^{12}$.

Значительная роль рестриктивных мер в отношении тяжелого пьянства как угрозы обществу объясняется также упоминаемостью в сообщениях СМИ субъектов реализации антиалкогольной политики. В контексте исследуемой темы наиболее часто называются высшие органы государственной власти (Госдума РФ, Правительство РФ, Совет Федерации), органы системы здравоохранения (Министерство здравоохранения РФ), органы экономики и финансов (Министерство финансов РФ, Министерство экономического развития РФ, Министерство промышленности и торговли РФ), силовые и надзорно-контрольные ведомства (Роспотребнадзор, Следственный комитет РФ, Федеральная антимонопольная служба РФ, Генпрокуратура РФ, Министерство обороны РФ, Министерство внутренних дел РФ, Верховный Суд РФ, Федеральная служба безопасности РФ, Федеральная служба исполнения наказаний РФ).

Из анализа видно, что самые заметные статьи касаются мер, имеющих рестриктивный потенциал (запреты на продажу алкоголя в выходные дни, продажу спиртосодержащей непищевой продукции, розничную продажу пива, борьбу с продажей суррогатов, сокращение алкоголепотребления в пунктах общественного питания, ограничение производства и оборота пива в пластиковой таре и т.д.) (таблицьь 1, 2).

\footnotetext{
9 Польгуева Е. (2016) Смертоносный «Боярышник» // Советская Россия. 20 декабря 2016 // http://www.sovross. ru/articles/1495/29292/comments/1; Юдин Ю. (2016) Осторожно, суррогат! // Областная. 21 декабря 2016 // http://www.ogirk.ru/2016/12/21/ostorozhno-surrogat/; Польгуева Е. (2016) Алкогольная катастрофа // Советская Россия. 22 декабря 2016 // http://www.sovross.ru/articles/1496/29357/comments/4; Иващенко Т. (2016) Алкогольная русская рулетка в Иркутске // ИА Regnum. 27 декабря 2016 // https://regnum.ru/news/2222234.html

10 Мать-алкоголичка оставила больных детей приятелям (2017) // Saratovnews.ru. 12 мая 2017 // https://www.saratovnews.ru/news/2017/05/12/mat-alkogolichka-ostavila-bolnyh-detei-priyatelyam/

11 За алкоголиками надо проследить (2016) // Синегорье (Челябинск). 6 января 2016; Завьялов И. (2017) Как найти управу на вымогателя-алкоголика // Читинское обозрение. 7 сентября 2017 // http://obozrenie-chita.ru/article/ uprava-na-vymogatelya; Алкоголиков и наркоманов будут искать в поликлиниках (2017) // Наша версия. 14 августа 2017; Быкова М. (2016) Алкоголикам спокойная жизнь не светит // В краю родном \# Елец. № 52-53 (9703-9704). 23 апреля 2016.

12 Байназаров Н. (2017) Банду продавщиц опасного алкоголя задержали на Ставрополье // Newstracker.ru. 24 апреля 2017 // https://newstracker.ru/news/incident/24-04-2017/bandu-prodavschits-opasnogo-alkogolya-zaderzhalina-stavropolie-2fff7c55-128b-402a-978b-de0a1d3c80eb; На иркутского замминистра завели дело из-за массовых отравлений «Боярышником» (2016) // Regions.ru. 27 декабря 2016 // http://regions.ru/news/2597497/
} 


\section{Таблица 1. Основные события, ранжированные по заметности в федеральных СМИ}

\begin{tabular}{|l|c|c|c|}
\hline Событие & $\begin{array}{c}\text { Количество } \\
\text { сообщений }\end{array}$ & $\begin{array}{c}\text { Охват } \\
\text { аудтории, } \\
\text { млнл. }\end{array}$ & $\begin{array}{c}\text { Заметность } \\
\text { события }\end{array}$ \\
\hline $\begin{array}{l}\text { Борьба с продажей и употреблением суррогатного алкоголя } \\
\text { в связи с массовым отравлением настойкой боярышника } \\
\text { в Иркске }\end{array}$ & 131 & 29,3 & 185,21 \\
\hline Розничная продажа алкоголя в интернете & 59 & 17,9 & 79,10 \\
\hline Запрет продажи алкоголя в выходные дни & 48 & 9,9 & 52,30 \\
\hline $\begin{array}{l}\text { Мапрет розничной продажи пива, инициированный } \\
\text { Минфином РФ }\end{array}$ & 30 & 7,5 & 47,96 \\
\hline Запрет пива в пластиковой 1,5-литровой таре & 24 & 5,0 & 34,03 \\
\hline $\begin{array}{l}\text { Законопроект о возвращении продажи алкоголя у школ } \\
\text { и поликлиник, инициированный Минпромторгом РФ }\end{array}$ & 18 & 3,4 & 29,85 \\
\hline Федеральный рейтинг трезвости регионов & 16 & 4,1 & 24,54 \\
\hline Запрет скидок на алкоголь & 31 & 5,8 & 22,66 \\
\hline Запрет продажи алкоголя в Чечне & 18 & 3,4 & 20,07 \\
\hline Экспорт пива на Украину & 10 & 2,1 & 19,74 \\
\hline
\end{tabular}

\section{Таблица 2. Основные события, ранжированные по заметности в региональных СМИ}

\begin{tabular}{|l|c|c|c|}
\hline Событие & $\begin{array}{c}\text { Количество } \\
\text { сообщений }\end{array}$ & $\begin{array}{c}\text { Охват } \\
\text { аудтории, } \\
\text { млел. }\end{array}$ & $\begin{array}{c}\text { Заметность } \\
\text { события }\end{array}$ \\
\hline Запрет продажи алкоголя в выходные дни & 91 & 1,1 & 29,50 \\
\hline Высокий уровень потребления алкоголя на Дальнем Востоке & 42 & 0,4 & 17,01 \\
\hline $\begin{array}{l}\text { Запрет на продажу спиртосодержащей непищевой продукции } \\
\text { вФ, инициированный Роспотребнадзором }\end{array}$ & 65 & 1,3 & 16,87 \\
\hline $\begin{array}{l}\text { Запрет розничной продажи пива, инициированный } \\
\text { Минфином РФ }\end{array}$ & 29 & 0,3 & 16,29 \\
\hline $\begin{array}{l}\text { Законопроект о возвращении продажи алкоголя у школ } \\
\text { и поликлиник, инициированный Минпромторгом РФ }\end{array}$ & 33 & 0,3 & 14,68 \\
\hline Борьба с продажей и употреблением настойки боярышника & 34 & 0,9 & 14,59 \\
\hline $\begin{array}{l}\text { Запрет вейпов, кальянов и снижение потребления алкоголя } \\
\text { в ресторанах и кафе России }\end{array}$ & 31 & 0,4 & 14,45 \\
\hline Запрет пива в пластиковой 1,5-литровой таре & 32 & 0,3 & 14,00 \\
\hline
\end{tabular}


Поводом для конструирования масштабов тяжелого пьянства является эксплуатация преувеличенных суждений о размахе потребления суррогатного алкоголя, на которые указывает В.В. Радаев [Радаев 2017], хотя надежные систематические данные о таком потреблении в России отсутствуют [Радаев 2018, с. 32]. Ярким примером закрепления образа исключительности тяжелого пьянства как наиболее острой проблемы в исследуемый период становится информационный повод об отравлении суррогатным алкоголем в Иркутске ${ }^{13}$, который активно муссировался в СМИ.

Между тем А.Д. Казун и А.П. Казун справедливо отмечают, что «нельзя сказать, что гибель от алкогольного отравления является редким событием в современной России» [Казун А.Д., Казун А.П. 2017, с. 131]. Так, ежегодно в стране только за 1,5 недели новогодних праздников регистрируется в среднем 2500 чел., отравившихся алкоголем, из них погибают около 600 чел. [О реализации постановления 2017]. Специальное исследование А.В. Немцова, основанное на анализе 241,2 тыс. случаев смертей от отравления алкоголем в 2004-2016 гг., показало, что их максимум приходится на январь и связан с празднованием Нового года [Немц̧ов 2018, с. 155]. В этой связи следует отметить, что в числе умерших люди, которых нельзя назвать «тяжелыми пьяницами» или «алкоголиками». Тем не менее в СМИ культивируются проблемы, связанные с потреблением суррогатного алкоголя населением (будь то тяжелое пьянство или смертность). Согласно комментарию Г.Г. Онищенко, эта спланированная провокация нужна «для того, чтобы снова поднять истерические крики, что водка дорогая, надо снижать цену, для того чтобы споить окончательно все наше население» (цит. по: [Отравление в Иркутске 2016]).

Неслучайно пристальное внимание федеральных СМИ к теме борьбы с суррогатным алкоголем (связанной с отравлением метиловым спиртом в Иркутске) сменяется ее невысокой значимостью для региональных СМИ. Можно было бы предположить, что для жителей регионов проблема Иркутска остается проблемой Иркутска, которая вряд ли коснется их самих (локальность), тогда как на федеральном уровне эта тема воспринимается как общезначимая (глобальность). Парадокс состоит в том, что отравление произошло в одном из городов России, однако, как замечают А.Д. Казун и А.П. Казун, проблема конструируется как общероссийская. По их мнению, данная ситуация, возникшая в отдельном городе, «может типизироваться и описываться как потенциально возможная в других регионах России» [Казун А.Д., Казун А.П. 2017, с. 131]. Приведенную мысль можно дополнить предположением, что проблема видится значимой для регионов с позиции федеральных СМИ, в самих же регионах восприятие ситуации несколько иное (таблиць 1, 2). Вероятно, это объясняется высокой концентрацией на федеральном уровне акторов, заинтересованных в регулировании вопроса суррогатного алкоголя в свою пользу. Так, информационный повод об Иркутске послужил аргументом для развития такого инструмента государственного контроля над

\footnotetext{
13 Новые жертвы. Люди уже привыкли пить «Боярышник» (2016) // Меtro \# Москва. № 187 (236/3632). 21 декабря 2016; Баясхалан Г. (2016) Боярышник» со вкусом смерти // Информ-полис (Улан-Удэ). 28 декабря 2016; Халезова Н. (2017) Смерть с запахом боярышника. Как бороться с пагубным пристрастием? // Аргументы и Факты \# Нижний Новгород. 17 февраля 2017 // http://www.nn.aif.ru/society/details/smert_s_zapahom_boyaryshnika_kak_borotsya_s_pagubnym_pristrastiem
} 
рынком алкогольной продукции, как «Единая государственная автоматизированная информационная система» (ЕГАИС), которая требует непрерывного совершенствования и соответствующих объемов бюджетного финансирования, и для данного события СМИ добились наибольшей заметности (таблицяа 1). Вместе с тем из анализа видно, что каждую обсуждаемую меру антиалкогольной политики сопровождают две противоположные группы интересов, где, с одной стороны, защищаются приоритеты бизнеса, с другой, отстаивается право граждан на жизнь и здоровье:

- сохранение ограничений продажи алкоголя у школ и больниц («Минпромторг: запрет на продажу алкоголя вблизи школ и больниц нанес ущерб малому бизнесу» ${ }^{14} / /$ «Камчатка: идея снять запрет на продажу алкоголя возле школ - безумие» $\left.{ }^{15}\right)$;

- ужесточение регулирования продажи косметических спиртосодержащих средств («Производители предупредили власти о дефиците косметических средств» ${ }^{16} / /$ «Роспотребнадзор: рынку косметики не грозят запреты на продукцию со спиртом» $\left.{ }^{17}\right)$;

- ограничение продажи сухого алкоголя («В России могут запретить пудру, румяна и духи из-за ограничения продажи сухого алкоголя» ${ }^{18} / /$ «Роспотребнадзор: парфюмерный рынок не пострадает от запрета сухого алкоголя» $\left.{ }^{19}\right)$;

- сокращение доступности алкоголя в выходные дни («В Минпромторге РФ

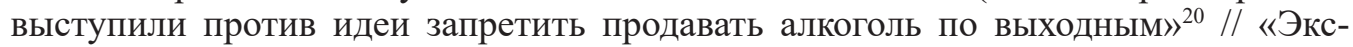
перт Минздрава надеется на введение запрета продажи алкоголя по выходным в 2017 г.» ${ }^{21}$ );

- запрет проведения скидочных акций на алкоголь («Российские пивовары не поддержали введение запрета скидок на алкоголь» 22 // «Роспотребнадзор выступил за запрет скидочных акций на алкоголь» ${ }^{23}$;

\footnotetext{
14 Минпромторг: запрет на продажу алкоголя вблизи школ и больниц нанес ущерб малому бизнесу (2016) // TACС. 24 февраля 2016 // https://tass.ru/ekonomika/2692697

15 Камчатка: идея снять запрет на продажу алкоголя возле школ - безумие (2016) // ИA Regnum. 25 февраля 2016 // https://regnum.ru/news/2085696.html

16 Буланов К. (2016) Производители предупредили власти о дефиците косметических средств // РБК. 28 декабря 2016 // https://www.rbc.ru/business/28/12/2016/58640c1a9a79476c1a0c16ea

17 Роспотребнадзор: рынку косметики не грозят запреты на продукцию со спиртом (2016) // РИА Новости. 29 декабря 2016 // https://ria.ru/20161229/1484877759.html

18 В России могут запретить пудру, румяна и духи из-за ограничения продажи сухого алкоголя (2016) // ИА Псковское агентство информации. 18 ноября 2016 // https://informpskov.ru/news/227970.html

19 Роспотребнадзор: парфюмерный рынок не пострадает от запрета сухого алкоголя (2016) // РИА Новости. 18 ноября 2016 // https://ria.ru/20161118/1481647616.html

20 Бабкина А. (2017) В Минпромторге РФ выступили против идеи запретить продавать алкоголь по выходным // ИА Версия-Саратов. 18 июля 2017 // https://nversia.ru/news/v-minpromtorge-rf-vystupili-protiv-idei-zapretit-prodavat-alkogol-po-vyhodnym/

21 Эксперт Минздрава надеется на введение запрета продажи алкоголя по выходным в 2017 г. (2017) // ТАСС. 17 июля 2017 // https://tass.ru/obschestvo/4419699

22 Российские пивовары не поддержали введение запрета скидок на алкоголь (2017) // РИА Новости. 6 февраля 2017 // https://ria.ru/20170206/1487300283.html

23 Роспотребнадзор выступил за запрет скидочных акций на алкоголь (2017) // РИА Новости. 6 февраля 2017 // https://ria.ru/20170206/1487238683.html
} 
- ценовое регулирование продажи алкоголя («Минэкономразвития хочет снизить цены на спиртное и разрешить его продажу на заправках...» ${ }^{24} / /$ «Снижение цен на алкоголь приведет к спаиванию россиян» ${ }^{25}$ );

- запрет на продажу алкоголя на кассах супермаркетов («Минпромторг выступил против запрета на продажу “чекушек” на кассах» ${ }^{26} / /$ «Минздрав поддерживает запрет на продажу чекушек на кассах супермаркетов» ${ }^{27}$ ) и т.д.

Мнения расходятся и в оценках алкогольной ситуации («Россияне стремительно трезвеют» ${ }^{28} / /$ «В стране запредельное потребление алкоголя по сравнению с царской Россией» $\left.{ }^{29}\right)$. Вместе с тем внутри групп интересов также наблюдается противостояние, особенно это заметно в отношении субъектов, заинтересованных в развитии рынка алкоголя ${ }^{30}$.

В заголовках новостных медиа четко прослеживается указание на двойственность антиалкогольной политики, а именно, с одной стороны, стремление получать доходы от регулирования алкогольного рынка, с другой, заботиться о здоровье населения. По мнению главы Федеральной антимонопольной службы (ФАС) России И.Ю. Артемьева, «государство должно выбрать, что оно хочет: еще больше уменьшить риск алкоголизации населения - это важная задача, при этом убить весь малый бизнес в этой сфере. Что хуже из двух зол, это выберет государство, это вопрос политиков» ${ }^{31}$. В этой связи равнозначными в СМИ представляются темы сохранения здоровья и обеспечения экономической прибыли ${ }^{32}$ (иногда заголовки приобретают абсурдное звучание $\left.{ }^{33}\right)$.

В целом, меры антиалкогольной политики оцениваются различными группами давления с точки зрения содержательности по-разному. В пользу развития

\footnotetext{
24 Минэкономразвития хочет снизить цены на спиртное и разрешить его продажу на заправках. Разработка предложения будет завершена к маю 2017 года (2016) // ИА 7 новостей. 15 декабря 2016.

25 Снижение цен на алкоголь приведет к спаиванию россиян (2016) // ИА Хакасия. 30 сентября 2016 // http:/www.19rus.info/index.php/ekonomika-i-finansy/item/55583-v-rossii-v-usloviyakh-ozhidaemogo-rosta-tsenpredlozhili-snizit-stoimost-butylki-vodki

26 Минпромторг выступил против запрета на продажу «чекушек» на кассах (2017) // ИA Rambler News Service. 24 июля 2017 // https://rns.online/consumer-market/Minpromtorg-vistupil-protiv-zapreta-na-prodazhu-chekushek-nakassah--2017-07-24/

27 Бахарева Н. (2017) Минздрав поддерживает запрет на продажу чекушек на кассах супермаркетов // Московская правда. 24 июля 2017 // http://mospravda.ru/2017/07/24/44388/

28 Россияне стремительно трезвеют (2017) // ИА УралИнформБюро. 24 января 2017 // https://spb.uralinform.ru/news/society/266736-rossiyane-stremitelno-trezveyut/

29 В стране запредельное потребление алкоголя по сравнению с царской Россией. Мнение Г. Онищенко (2017) // ИА Rambler News Service. 24 января 2017 // https://rns.online/opinions/V-strane-zapredelnoe-potreblenie-alkogolyapo-sravneniyu-s-tsarskoi-Rossiei-2017-01-24/

30 Трутнев О. (2017) Пивовары тянут время на себя // Коммерсантъ. 27 июня 2017 // https://www.kommersant.ru/ doc/3336509; СМИ: Запрет на продажу алкоголя в ПЭТ лоббируют производители стекла (2016) // ИA Regnum. 3 марта 2016 // https://regnum.ru/news/2091126.html

31 ФАС: Запрет продажи алкоголя для ИП может «убить» малый бизнес в этой сфере (2016) // Агентство городских новостей «Москва». 23 ноября 2016 // https://www.mskagency.ru/materials/2610835

32 След нелегальной водки тянется из Кабардино-Балкарии в Хабаровский край (2016) // ИА AmurMedia. 12 мая 2016 // https://amurmedia.ru/news/505361/; Мантуров призвал найти баланс между запретами и стимулированием алкогольного рынка (2016) // ИА Rambler News Service. 27 декабря 2016 // https://rns.online/consumermarket/Manturov-prizval-naiti-balans-mezhdu-zapretami-i-stimulirovaniem-alkogolnogo-rinka-2016-12-27/
}

33 Акцизы или спаивание населения: в Чувашии решают, что важнее (2017) // ИА Regnum. 26 мая 2017 // https://regnum.ru/news/2280181.html 
алкогольного бизнеса и значимой для здоровьесбережения населения преподносится борьба с потреблением суррогатного алкоголя, хотя она направлена лишь на интенсивно пьющих людей ${ }^{34}$. Допускается, что среднестатистический россиянин может себе позволить потребление алкоголя как «культурный человек» ${ }^{35}$. Также можно встретить мнения о том, что ограничить алкоголепотребление для широких масс населения - значит ограничить людей в их правах ${ }^{36}$. И напротив, борцы за общественное здоровье стремятся найти универсальные меры, которые влияли бы не только на интенсивно пьющих граждан, но на общество в целом ${ }^{37}$, однако их предложения, затрагивающие интересы широких масс населения, подвергаются контрриторике и в дальнейшем не находят своего воплощения в реальности ${ }^{38}$.

В идеале декларируемые высшие цели антиалкогольной политики государства связаны с такой мягкой стратегией, как формирование стиля жизни без алкоголя среди широких масс населения, и направлены на общее снижение уровня алкоголепотребления в обществе [Распоряжение Правительства 2009]. На большой прессконференции, прошедшей 23 декабря 2016 г., В.В. Путин отметил, что «это не могут быть меры запретительного характера, хотя некоторые вопросы должны лежать и в этой сфере. $<\ldots>$ Это и воспитательная [работа], это и работа средств массовой информации» [Большая пресс-конференция Владимира Путина 2016]. Вместе с тем сообщения новостных медиа, сфокусированные на практиках лишь интенсивного пьянства и рестриктивных инструментах влияния на него, только укрепляют сформировавшийся в общественном мнении карательный образ антиалкогольных мер и тем самым ставят под сомнение главные задачи антиалкогольной политики.

Следует отметить, что многие из проведенных в жизнь ограничительно-запретительных мер, объявлявшихся ранее в СМИ нереализуемыми, сегодня внесли свой вклад в сокращение общего потребления алкоголя населением. Это подтверждается исследованиями М.Г. Колосницыной, М.Т. Ситдикова, А.С. Скоробогатова, Н.А. Хоркиной и других [Колоснищына, Хоркина, Волков 2018; Колосницьна, Хоркина, Ситдиков 2017; Скоробогатов 2016]. В то же время фокусирование субъектов предотвращения алкоголизации населения исключительно на рестриктивных мерах ограничивает эффективность осуществляемой в стране антиалкогольной политики. Мягкая превентивная деятельность, соответствующая ее идеалам, пока остается второстепенной и не позиционируется в СМИ как равнозначный компонент антиалкогольной политики государства, а акцент делается на локаль-

34 Депутат: с потребителями «Боярышника» надо действовать жестко (2016) // ИА Владньюс.инфо. 27 декабря 2016 // https://vladnews.ru/2016-12-27/101387/deputat potrebitelyami; Гридин И. (2016) Минпромторг: водку нужно сделать вдвое дешевле. Качественный и доступный алкоголь пополнит бюджет более чем на 20\% // РИА Новый День. 29 сентября 2016 // https://newdaynews.ru/economy/580884.html

35 Депутат Госдумы Ольга Епифанова: культурный человек может выпить и в ночное время (2016) // ИА Rusnord. 17 июня 2016 // http://rusnord.ru/politic/36101-deputat-gosdumy-olga-epifanova-kulturnyy-chelovekmozhet-vypit-i-v-nochnoe-vremya.html

36 Правительство защищает право россиян на алкоголь (2016) // ИА Политсовет. 17 февраля 2016 // http://politsovet.ru/51084-pravitelstvo-zaschitit-pravo-rossiyan-na-alkogol.html

37 Нилов О. (2016) Олег Нилов: необходимо поставить реальный заслон наглому и циничному лоббированию интересов алкогольной мафии // Regions.Ru / Новости Федерации. 15 января 2016// http://regions.ru/news/2569743/; «Необходимо вести здоровую политику сбережения нации»: Вдовин об инициативе Минздрава запретить продажу алкоголя в выходные (2017) // ИА Орловские новости. 18 июля 2017 // https://newsorel.ru/fn_279635.html

38 Депутат: эксперименты с запретом продажи алкоголя в выходные себя не оправдывают (2017) // ИА Росбалт. 17 июля 2017 // http://www.rosbalt.ru/russia/2017/07/17/1631230.html 
ном аспекте процесса алкоголизации населения. Не являются объектом внимания СМИ и широко распространенные нормативные практики потребления алкоголя, характерные для большинства населения, хотя они не меньше провоцируют негативные социальные последствия [Kreitman 1986; Skog 1999; Gmel, Klingemann, Müller, Brenner 2005].

По мнению М. Эделмана, видимость решения проблемы создается ее устранением из общего дискурса либо ее обсуждением в иных терминах, будто это другая проблема [Эделман 2007, с. 186]. Как видно из результатов контент-анализа, тема алкоголизации населения замещается ее узким аспектом. Риторика преодоления тяжелого пьянства конструируется преувеличением масштабов потребления суррогатного алкоголя и полемикой о применении исключительно рестриктивных и фискальных мер антиалкогольной политики. Как отмечает О.А. Матвейчев, «СМИ навязывают проблему. Не решение проблемы, не оценки, а именно проблему, которая будет считаться для данного человека, для данного общества самой важной. И вот здесь, конечно, открывается большой простор для манипуляций» [Матвейчев 2016, с. 163]. В результате складывается парадоксальная ситуация: риторике преодоления тяжелого пьянства рестриктивными методами противоречит отчуждающий образ рестриктивной государственной антиалкогольной политики. В терминологии П. Ибарры и Дж. Китсьюза «утверждения-требования» на тему тяжелого пьянства обесцениваются «контрриторическими стратегиями» [Ибарра, Китсьюз 2007].

\section{Контрриторические стратегии репрезентации антиалкогольной политики}

Под «утверждениями-требованиями» в настоящей статье понимаются меры антиалкогольной политики государства, ставшие объектом репрезентации новостными медиа. П. Ибарра и Дж. Китсьюз отмечают, что исследование конструирования социальных проблем должно фокусироваться не только на одобрении и выдвижении «утверждений-требований», но и на их вытеснении и дискредитации [Ибарра, Китсьюз 2007, с. 62], поскольку контрриторика блокирует призывы к действию. В связи с этим с помощью методологии П. Ибарры и Дж. Китсьюза целесообразно описать стратегии контрриторики репрезентации антиалкогольной политики (maблица 3). Среди них следует отметить «декларацию бессилия», отражающую ранее упоминаемое противоречие между риторикой преодоления тяжелого пьянства рестриктивными мерами и отчуждающим образом рестриктивной антиалкогольной политики государства ${ }^{39}$. Данная стратегия «предполагает проявление морального сочувствия и вместе с тем указание на истощение имеющихся ресурсов, не позволяющее справиться с проблемой» [Ибарра, Китсьюз 2007, с. 87]. В СМИ фактически указывается на безвыходность ситуации и фатальность алкоголизации общества ${ }^{40}$.

\footnotetext{
39 Виталий Шуба: «В борьбе с алкоголизмом запретительные меры не очень помогают» (2017) // ИА Альтаир. 27 января $2017 / / \mathrm{https} / / / \mathrm{altairk} . r u / \mathrm{new} /$ policy/alcoholism_prohibitive_measures_are_not_very_helpful

40 Завтра в России разрешат продавать аналоги «Боярышника»-убийцы (2017) // ИА Свободные новости. 24 января 2017 // https://fn-volga.ru/news/view/id/59944
} 


\section{Таблица 3. Стратегии и лейтмотивы контрриторики в отношении антиалкогольной по- литики, выявленные с помощью методологии И. Ибарры и Дж. Китсьюза}

\begin{tabular}{|c|c|c|}
\hline $\begin{array}{l}\text { Класс стратегий } \\
\text { контрриторики } \\
\text { по П. Ибарре } \\
\text { и Дж. Китсьюзу }\end{array}$ & $\begin{array}{l}\text { Стратегии } \\
\text { контрриторики }\end{array}$ & Лейтмотивы контрриторики \\
\hline \multirow{5}{*}{$\begin{array}{l}\text { «Сочувствующая» } \\
\text { контрриторика }\end{array}$} & Натурализация & $\begin{array}{l}\text { «России неоправданно присвоили статус самой пьющей } \\
\text { страны» }\end{array}$ \\
\hline & $\begin{array}{l}\text { Контрриторика за- } \\
\text { трат, связанных с } \\
\text { исправлением }\end{array}$ & $\begin{array}{l}\text { «Розница потеряла } 745 \text { миллиардов из-за регулирования } \\
\text { алкоголя» } 42\end{array}$ \\
\hline & Декларация бессилия & $\begin{array}{l}\text { «Антиалкогольная политика Якутии: пока больше } \\
\text { минусов» } 43\end{array}$ \\
\hline & Перспективизация & $\begin{array}{l}\text { «Общественникам объяснили, почему не получится за- } \\
\text { претить продажу алкоголя покупателям младше } 21 \text { года» }{ }^{44}\end{array}$ \\
\hline & Критика тактики & $\begin{array}{l}\text { «С «сухим законом» важно не переборщить» }{ }^{45} ; \\
\text { «Надо ли ограничивать продажу алкоголя?» }{ }^{46}\end{array}$ \\
\hline \multirow{4}{*}{$\begin{array}{l}\text { «Несочувствующая» } \\
\text { контрриторика }\end{array}$} & Антитипизация & $\begin{array}{l}\text { «Минфин объявил войну “кондитерскому» } \\
\text { алкоголизму”» } 47\end{array}$ \\
\hline & $\begin{array}{l}\text { Контрриторика опро- } \\
\text { вергающих историй }\end{array}$ & $\begin{array}{l}\text { «Власти предсказали рост самогоноварения из-за } \\
\text { ограничения продаж алкоголя» }{ }^{48}\end{array}$ \\
\hline & $\begin{array}{l}\text { Контрриторика } \\
\text { неискренности }\end{array}$ & $\begin{array}{l}\text { «Матвей Лыткин: государству не выгодно массовое } \\
\text { пьянство среди населения» } 49\end{array}$ \\
\hline & $\begin{array}{l}\text { Контрриторика } \\
\text { истерии }\end{array}$ & $\begin{array}{l}\text { «Рынок косметики близок к коллапсу из-за ограничений } \\
\text { на “Боярышник”» }\end{array}$ \\
\hline
\end{tabular}

41 Багров И. (2017) России неоправданно присвоили статус самой пьющей страны // Мир новостей. 9 декабря 2017 // https://mirnov.ru/lenta-novostej/rossii-neopravdanno-prisvoili-status-samoi-pyuschei-strany.html

42 Перцева Е. (2016) Розница потеряла 745 миллиардов из-за регулирования алкоголя // Известия. 9 декабря 2016 // https://iz.ru/news/650234

43 Антиалкогольная политика Якутии: пока больше минусов (2017) // ИА Regnum. 26 апреля 2017 // https://regnum.ru/news/2268014.html

44 Аксенов А. (2017) Общественникам объяснили, почему не получится запретить продажу алкоголя покупателям младше 21 года // ИА Версия-Саратов. 28 июня 2017 // https://nversia.ru/news/obschestvennikam-obyasnilipochemu-ne-poluchitsya-zapretit-prodazhu-alkogolya-pokupatelyam-mladshe-21-goda/

45 C «сухим законом» важно не переборщить. В Челябинске обсудили инициативу о запрете продажи алкоголя в праздничные дни (2017) // Накануне.ру. 17 февраля 2017 // https://www.nakanune.ru/news/2017/02/17/22461400/

46 Надо ли ограничивать продажу алкоголя? (2017) // Комсомольская правда \# Москва. 28 июня 2017. С. 3.

47 Перцева Е. (2017) Минфин объявил войну «кондитерскому» алкоголизму // Известия. № 67 (29805). 14 апреля 2017. С. 6.

48 Власти предсказали рост самогоноварения из-за ограничения продаж алкоголя (2017) // РБК. 17 июля 2017 // https://www.rbc.ru/rbcfreenews/596cec479a79477287bc4df5

49 Яковлев А. (2016) Матвей Лыткин: Государству не выгодно массовое пьянство среди населения // ИА Якутское - Саха. 2 марта 2016 // http://archive.ysia.ru/glavnoe/matvej-lytkin-gosudarstvu-ne-vygodno-massovoe-pyanstvosredi-naseleniya/

50 Рынок косметики близок к коллапсу из-за ограничений на «Боярышник» (2016) // ИА Хабаровский край сегодня. 29 декабря 2016 // https://todaykhv.ru/news/society/1837/ 
Не менее актуальна в отношении тяжелого пьянства контрриторика натурализации, которая нередко используется для обозначения проблемы российского пьянства как несущественной в мировых масштабах. Контрриторика затрат, связанных с исправлением, содержит опасения, что антиалкогольная политика не оправдает себя. Наличие контрриторики истерии хорошо подмечено Г.Г. Онищенко, слова которого цитируются в заголовках сообщений ${ }^{51}$. Эта контрриторика особенно четко прослеживается в резких высказываниях его оппонентов о рестриктивной антиалкогольной политике, связанных с клише «россияне будут травиться суррогатами», «алкогольный рынок уйдет в тень» ${ }^{52}$. Подобные формулировки заголовков статей содержат риторику устрашения, создают крайне негативный образ не только антиалкогольной политики, но и ее инициаторов. Провокационность заголовков в качестве лейтмотивов, репрезентирующих тему преодоления алкоголизации населения, дискредитирует антиалкогольную политику государства и драматизирует ее исход, а ее отчуждающий и даже катастрофический образ конструируется посредством ряда стратегий, которые также можно назвать контрриторическими. По результатам контент-анализа нами была построена типология контрриторических стратегий в отношении мер антиалкогольной политики:

- иронизация - высмеивание мер антиалкогольной политики государства ${ }^{53}$;

- вульгаризация - грубое упрощение и искажение смысла мер предотвращения алкоголизации населения ${ }^{54}$;

- советизация - формирование ассоциативных связей между горбачевской антиалкогольной кампанией и современной антиалкогольной политикой при помощи обращения к советским лозунгам ${ }^{55}$;

- мифологизация - культивирование вымышленных представлений об эффективности антиалкогольной политики ${ }^{56}$;

- гиперболизация - эксплуатация преувеличенных суждений об антиалкогольной политике ${ }^{57}$;

51 Петрова И. (2017) Геннадий Онищенко возмущен истерикой вокруг запрета продажи алкоголя в выходные // Riafan. 18 июля 2017 // https://riafan.ru/872471-gennadii-onishchenko-vozmushchen-isterikoi-vokrug-zapretaprodazhi-alkogolya-v-vyhodnye

52 Депутат ГД: Запрет продажи алкоголя в выходные приведет к контрафакту и нелегальной торговле (2017) // ИА Москва. 17 июля 2017 // https://www.mskagency.ru/materials/2686314

53 Фомченков Т. (2016) Сухой алкоголь подмочил свою репутацию // ИА ИНВУР. 26 марта 2016 // http://www. invur.ru/index.php?page=news\&id=112719; Ручко С. (2017) Между первой и второй - перерыв на выходной? // Комсомольская правда \# Тула. №80 (26706) 19-20 июля 2017. С. 3; Петров И. (2017) А не попить ли пивка? // Российская газета. 25 мая 2017 // https://rg.ru/2017/05/25/na-igrah-kubka-konfederacij-razreshili-prodazhu-piva.html

54 Сизова Н. (2017) Пили. Пьют. Будут пить? // ИА ПензаИнформ. 26 июля 2017 // http://www.penzainform.ru/ press/pp/2017/07/26/pili_pyut_budut_pit.html; Эксперты: массовое употребление «Боярышника»-результат акцизной политики (2016) // ТАСС. 20 декабря $2016 / /$ https://tass.ru/ekonomika/3891855

55 Пьянству - бой! (2016) // Аргументы и Факты \# Чебоксары. 28 сентября 2016; Маевская Н. (2017) В Госдуме призвали вернуться к «советскому» запрету метилового спирта // ИА Волга-Каспий. 14 февраля 2017 // https://volga-kaspiy.ru/know/v-gosdume-prizvali-vernutsya-k-sovetskomu-zapretu-metilovogo-spirta.html

56 Рост цен на водку: «Как пили, так и будут пить», только «суррогат» (2017) // ИА Regnum. 29 августа 2017 // https://regnum.ru/news/2314889.html; Малахевич А. (2017) Самогон уходит в тень // Четверг. № 26 (1334). 06 июля 2017. С. 10.

57 Ритейлеры предупредили об угрозе роста воровства при запрете продажи «чекушек» на кассах (2017) // ИА Rambler News Service. 24 июля 2017 // https://rns.online/consumer-market/Riteileri-predupredili-o-ugroze-rostavorovstva-pri-zaprete-prodazhi-chekushek-na-kassah-2017-07-24/ 
- десакрализация - обесценивание смыслов антиалкогольной политики ${ }^{58}$;

- патологизация - придание сомнительности адекватности в реализации антиалкогольных мер ${ }^{59}$.

По мнению Д. Мойера и Р. Клигнета, одни группы людей, представляющие социальные проблемы, драматизируют их, другие же заинтересованные акторы в отношении этих проблем используют дедраматизирующие стратегии (цит. по [Хилгартнер, Боск 2007, с. 158]). Однако следует отметить, что в случае нагнетания проблемы тяжелого пьянства эти стратегии против нее не используются. Напротив, как сама проблема, так и пути ее решения подвергаются интенсивному преувеличению. Дедраматизирующие стратегии применяются, скорее, к повседневному аспекту потребления, его нормативной составляющей (так называемому культурному потреблению). Представления о том, что этот аспект вносит существенный вклад в процесс алкоголизации населения, делая практики потребления алкоголя массовыми и рутинизированными, и что нормативные потребители алкоголя («культурно пьющие») могут обращаться к практикам ненормативного потребления алкоголя (иногда «напиваться», например) и т.д., способны проблематизировать тему нормативного потребления алкоголя как латентного, массового, привычного явления. Дедраматизация этой темы выражается в ее представлении как незначимой и несущественной по сравнению с тяжелым пьянством. Как отмечают Д. Мойер и Р. Клигнет, «в случае дедраматизации используются такие стратегии, как отрицание существования предполагаемого условия или предполагаемой ситуации, утверждения, что другие вопросы являются более неотложными или что наносимый вред имеет другие причины, не те, о которых говорит конкурирующая группа функционеров, выставление противоположного лагеря несведущим и нерациональным, утверждения, что данная ситуация естественна, приемлема и неизбежна и что решения неизвестны, неосуществимы, неприемлемы или их вообще не существует» (цит. по [Хилгартнер, Боск 2007, с. 182]).

Таким образом, одни явления возводятся в ранг социальной проблемы, другие же обесцениваются стратегиями дедраматизации. Наряду с этим намеренно искажаются пути решения нагнетающихся социальных проблем (тяжелого пьянства) и применяются соответствующие контрриторические стратегии, формирующие восприятие процесса алкоголизации населения как фатального.

\section{Заключение}

Конструирование образа антиалкогольной политики в СМИ не может рассматриваться в отрыве от характера проблематизации ее объекта - процесса алкоголиза-

\footnotetext{
58 Сухой уикэнд: в Якутии неоднозначно относятся к идее запретить продавать алкоголь в выходные (2017) // ИА Якутское - Саха. 08 августа 2017 // http://ysia.ru/suhoj-uikend-v-rossii-hotyat-zapretit-prodavat-alkogol-v-vyhodnye/; Депутат предложил сделать в новогодние праздники «алкогольную поблажку» (2017) // ИА Саратовский регион. 7 декабря 2017 // http://sarreg.ru/deputat-predlozhil-sdelat-v-novogodnie-prazdniki-alkogolnuyu-poblazhku-25495.html 59 (2017) В Минпромторге удивились инициативе запретить продажу алкоголя по выходным // ИА Ianews.ru. 17 июля 2017 // https://ianews.ru/articles/101217/
} 
ции населения, который в новостных медиа дифференцируется и сводится к феномену тяжелого пьянства.

Как показало исследование, усилению внимания к тяжелому пьянству и соответствующим мерам его преодоления за исследуемый период послужил информационный повод об отравлении суррогатным алкоголем в Иркутске. Несмотря на то, что инцидент произошел в одном из регионов России, заинтересованность в драматизации данной темы оказалась выше у федеральных СМИ, нежели у региональных, что указывает на целенаправленность продвижения тех или иных интересов в отношении мер антиалкогольной политики на общероссийском уровне. Активное муссирование темы в СМИ актуализировало ограничительные и фискальные меры борьбы с нелегальным рынком алкоголя и тяжелым пьянством. В то же время мягкие меры социальной превенции, соответствующие идеалам антиалкогольной политики государства, остались без внимания. Таким образом, проблематизация одних аспектов процесса алкоголизации населения в СМИ сменяется депроблематизацией других, и на этой основе производятся дифференциация и отбор мер антиалкогольной политики для их освещения.

Наряду с изображением катастрофичности масштабов распространения наиболее тяжелых и опасных форм потребления алкоголя замалчивается тема распространения повседневных форм потребления алкоголя населением, характерных для большинства граждан. Меры, направленные на исправление алкогольной ситуации в целом, выдвигаемые новостными медиа в качестве резонансных, подвергаются явной и латентной критике, что девальвирует статус процесса алкоголизации населения в какой бы то ни было его форме. Несмотря на проблематизацию образа тяжелого пьянства, риторика его преодоления одновременно обесценивается контрриторическими стратегиями, которые касаются в том числе и преодоления алкоголизации населения в целом.

С помощью методологии П. Ибарры и Дж. Китсьюза на основе контент-анализа нами были определены основные лейтмотивы, характеризующие образ антиалкогольной политики, конструируемый новостными медиа. Установлено, что используемая в СМИ контрриторика препятствует адекватному восприятию ее мер, подчеркивает их неспособность справиться с поставленными задачами и блокирует выдвигаемые призывы к действию. Она содержит провокационные формулировки, содержащие риторику устрашения, создает отчуждающий и даже катастрофический образ антиалкогольной политики.

По результатам контент-анализа также построена авторская типология контрриторических стратегий в отношении антиалкогольной политики. Так, посредством иронизации осуществляется высмеивание ее мер, а с помощью вульгаризации производятся упрощение и искажение их смыслов. С использованием стратегии советизации делаются попытки провести аналогию между нынешней антиалкогольной политикой и горбачевской антиалкогольной кампанией. Не менее активно используется мифологизация, связанная с культивированием вымышленных представлений об антиалкогольной политике государства. Кроме того, эксплуатируются приувеличительные суждения об антиалкогольной политике и ее последствиях, что выражается стратегией гиперболизации. Обесценивание смыслов антиалкогольной политики и придание сомнительности адекватности в реализации антиалкогольных мер производятся посредством десакрализации и патологизации. 
Таким образом, по результатам контент-анализа выявлено противоречие между риторикой преодоления тяжелого пьянства рестриктивными мерами и отчуждающим образом рестриктивной антиалкогольной политики государства. Следует отметить, что в новостных СМИ акцент делается не на предполагаемых конкретных результатах антиалкогольной политики, а на абстрактных, надуманных последствиях, и в конечном счете создается образ фатальности алкоголизации общества.

\section{Литература}

Алкоголизм, и как с ним бороться (2017) // ВЦИОМ. 11 сентября 2017. № 3463 // https://wciom.ru/index.php?id=236\&uid $=3578$

Безвредный алкоголь: миф или реальность? (2018) // ВЦИОМ. 21 сентября 2018. № 3768 // https://wciom.ru/index.php?id=236\&uid=9324

Бест Дж. (1) (2007) Ограничения строгой конструкционистской интерпретации социальных проблем // Социальные проблемы: конструкционистское прочтение. Хрестоматия. Казань: Изд-во Казанского ун-та. С. 115-144.

Бест Дж. (2) (2007) Социальные проблемы // Социальные проблемы: конструкционистское прочтение. Хрестоматия. Казань: Изд-во Казанского ун-та. С. 26-54.

Блумер Г. (2007) Социальные проблемы как коллективное поведение // Социальные проблемы: конструкционистское прочтение. Хрестоматия. Казань: Изд-во Казанского унта. С. $5-10$.

Большая пресс-конференция Владимира Путина (2016) // Президент России. 23 декабря 2016 // http://www.kremlin.ru/events/president/news/53573

Губит людей не пиво? (2017) // ВЦИОМ. 16 августа 2017. № 3442 // https://wciom.ru/index.php?id=236\&uid=116356

Демьянков В.3. (2017) Трансфер знаний и когнитивная манипуляция // Вопросы когнитивной лингвистики. № 4. С. 5-13.

Ибарра П., Китсьюз Дж. (2007) Дискурс выдвижения утверждений-требований и просторечные ресурсы // Социальные проблемы: конструкционистское прочтение. Хрестоматия. Казань: Изд-во Казанского ун-та. С. 55-114.

Казун А.Д., Казун А.П. (2017) Когда беда приходит не одна: освещение трех трагедий в российских СМИ // Мониторинг общественного мнения. № 3. С. 128-146. DOI: $10.14515 /$ monitoring.2017.3.09

Колосницына М.Г., Хоркина Н.А., Волков А.Ю. (2018) Внешние эффекты потребления алкоголя: влияние мер антиалкогольной политики на преступность // Вопросы экономики. № 3. С. 130-152.

Колосницына М.Г., Хоркина Н.А., Ситдиков М.Т. (2017) Ограничения торговли и потребление алкоголя: о результативности государственной политики // Проблемы прогнозирования. № 5. С. 116-128.

Лазарсфельд П., Мертон Р. (2002) Массовая коммуникация, массовые вкусы и организованное социальное действие // Массовая коммуникация в современном мире: методология анализа и практика исследований. Хрестоматия. М.: Едиториал УРСС. C. $139-150$.

Матвейчев O.А. (2016) Информационные войны XXI века. «Мягкая сила» против атомной бомбы. М.: Книжный мир.

Мейлахс П. (2004) Дискурс прессы и пресс дискурса: конструирование проблемы наркотиков в петербургских СМИ // Журнал социологии и социальной антропологии. № 4. C. $135-151$.

Немцов А.В. (2018) Смерти при отравлении алкоголем в январе в России (2004-2016 гг.) // Вопросы наркологии. № 2. С. 155-167. 
О реализации постановления по ограничению реализации спиртосодержащей непищевой продукции (2017) // Роспотребнадзор. 22 января 2017 // http://rospotrebnadzor.ru/about/ info/news/news details.php?ELEMENT ID=7713\&sphrase id=1385249

Отравление в Иркутске Онищенко назвал спланированным убийством людей (2016) // Говорит Москва. 19 декабря 2016 // https:/govoritmoskva.ru/news/103519/

Радаев В.В. (2017) Доклад на панельной сессии «Нелегальный рынок алкоголя: преувеличение или опасная реальность? // Форум «Алкогольный рынок: от запретов к развитию». Москва, 22 сентября 2017 // https://profibeer.ru/video/30687/

Радаев В.В. (2018) Королевство кривых зеркал: эволюция рынков нерегистрируемого алкоголя в России в 1980-2010-е годы // Мир России. Т. 27. № 3. С. 28-60. DOI: $10.17323 / 1811-038 X-2018-27-3-28-60$

Распоряжение Правительства РФ от 30 декабря 2009 г. N 2128-р «О Концепции реализации государственной политики по снижению масштабов злоупотребления алкогольной продукцией и профилактике алкоголизма среди населения РФ на период до 2020 г.» (2009) // https://base.garant.ru/12172220/

Скоробогатов А.С. (2016) Влияние политики ограничения ночной продажи крепкого алкоголя на потребление и злоупотребление алкоголем в России // Journal of Institutional Studies. T. 8. № 3. C. 72-90.

Спектор М., Китсьюз Дж. (1998) Конструирование социальных проблем // Контексты современности. Хрестоматия. Казань: АБАК. С. 75-78.

Употребление алкоголя (2017) // Левада-Центр. 18 мая 2017 // https://www.levada.ru/2017/05/18/upotreblenie-alkogolya/

ФАС: Запрет продажи алкоголя для ИП может «убить» малый бизнес в этой сфеpe (2016) // Москва. Агентство городских новостей. 23 ноября 2016 // https://mskagency.ru/materials/2610835

Хилгартнер С., Боск Ч.Л. (2007) Рост и упадок социальных проблем: концепция публичных арен // Социальные проблемы: конструкционистское прочтение. Хрестоматия. Казань: Изд-во Казанского ун-та. С. 145-184.

Эделман М. (2007) Конструирование социальных проблем как часть политического спектакля // Социальные проблемы: конструкционистское прочтение. Хрестоматия. Казань: Изд-во Казанского ун-та. С. 185-196.

Ясавеев И. Г. (2004) Конструирование социальных проблем средствами массовой коммуникации. Казань: Изд-во Казанского ун-та.

Ясавеев И. Г. (2007) Конструирование «не-проблем»: стратегии депроблематизации ситуаций // Социальные проблемы: конструкционистское прочтение. Хрестоматия. Казань: Изд-во Казанского ун-та. С. 255-275.

Cohen S. (1973) Folk Devils and Moral Panics: The Creation of the Mods and Rockers, St. Albans: Paladin.

Gmel G., Klingemann S., Müller R., Brenner D. (2001) Revising the Preventive Paradox: The Swiss Case // Addiction, no 96, pp. 273-284. DOI: 10.1046/j.1360-0443.2001.96227311.x

Kreitman N. (1986) Alchohol Consumption and the Preventive Paradox // British Journal of Addiction, vol. 81, no 3, pp. 353-363. DOI: 10.1111/j.1360-0443.1986.tb00342.x

Radaev V. (2017) A Crooked Mirror. The Evolution of Illegal Alcohol Markets in Russia since the Late Socialist Period // The Architecture of Illegal Markets: Towards an Economic Sociology of Illegality in the Economy (eds. Beckert J., Dewey M.), Oxford: Oxford University Press, pp. 218-241.

Skog O.-J. (1999) The Prevention Paradox Revisited // Addiction, vol. 94, no 5, pp. 751-757. 


\title{
The Construction of Russia's Anti-drinking Campaign in the Russian News Media: the Rhetoric of Overcoming Alcohol Abuse and Counter-rhetorical Strategies
}

\author{
Yu. BELOVA*
}

*Yuliya Belova - PhD in Sociology, Researcher, Laboratory for Studies in Economic Sociology, National Research University Higher School of Economics. Address: 11, Myasnitskaya St., Moscow, 101000, Russian Federation. E-mail: juliya01@mail.ru

Citation: Belova Y. (2019) The Construction of Russia's Anti-drinking Campaign in the Russian News Media: the Rhetoric of Overcoming Alcohol Abuse and Counter-rhetorical Strategies. Mir Rossii, vol. 28, no 3, pp. 155-175 (in Russian). DOI: $10.17323 / 1811-038 \mathrm{X}-2019-28-3-155-175$

\begin{abstract}
Through the lens of social constructivism, this article analyzes how the Russian news media portray the state anti-drinking campaign in Russia. In the first analytical stage, I consider the rhetoric of overcoming widespread alcoholism as a narrow aspect of the alcoholization of the population. In the second analytical stage, I focus on the counter-rhetoric strategies against the anti-drinking policies. By applying quantitative $(\mathrm{N}=37,903)$ and qualitative $(\mathrm{N}=10,002)$ content analysis to news media items published between 2016-2017 (using the Medialogia platform) I construct a typology of the counter-rhetorical strategies. The typology includes the following strategies: 1) ironization, ridiculing the effort of the state in overcoming alcoholism; 2) vulgarization, simplifying and distorting the meaning of the anti-alcohol measures; 3) sovietization, creating associations between current anti-drinking policies and Gorbachev's anti-alcohol campaign; 4) mythologizing, cultivating fictional ideas about the efficiency of the anti-drinking measures; 5) exaggeration, operating via exaggerated facts and judgments about the policies; 6) desacralization, depreciating their meanings; and 7) pathologization, questioning the adequacy of anti-drinking measures. The news media items and counter-rhetorical strategies are analyzed using the methodology developed by Ibarra and Kitsuse. I conclude that there is a contradiction between the rhetoric of overcoming widespread alcoholism and the alienating image of the state's highly restrictive anti-drinking policies. The counterrhetorical strategies which dramatize those policies maintain the perception that alcoholization is an overwhelming problem.
\end{abstract}

Key words: constructivism, anti-alcohol policy, deproblematization, alcoholization, alcoholism, counter-rhetorical strategies 


\section{References}

Alkogolizm, i kak s nim borot'sya [Alcoholism, and How to Deal with It] (2017). VCIOM, September 11, 2017, no 3463. Available at: https://wciom.ru/index.php?id=236\&uid=3578, accessed 15.05.2019.

Bezvrednyj alkogol': mif ili real'nost'? [Harmless Alcohol: Myth or Reality?] (2018). VCIOM, September 21, 2018, no 3768. Available at: https://wciom.ru/index.php?id=236\&uid=9324, accessed 15.05.2019.

Best J. (1) (2007) Ogranicheniya strogoj konstruktsionistskoj interpretatsii sotsial'nykh problem [The Limitations of the Strict Constructionist Interpretation of Social Problems]. Sotsial'nye problemy: konstruktsionistskoe prochtenie. Khrestomatiya [Social Problems: Constructionist Reading. Reader], Kazan: Publishing house of Kazan University, pp. 115-144.

Best J. (2) (2007) Sotsial'nye problemy [Social Problems]. Sotsial'nye problemy: konstruktsionistskoe prochtenie. Khrestomatiya [Social Problems: Constructional Reading. Reader], Kazan: Publishing house of Kazan University, pp. 26-54.

Blumer H. (2007) Sotsial'nye problemy kak kollektivnoe povedenie [Social Problems as Collective Behavior]. Sotsial'nye problemy: konstruktsionistskoe prochtenie. Khrestomatiya [Social Problems: Constructionist Reading. Reader], Kazan: Publishing house of Kazan University, pp. 5-10.

Bol'shaya press-konferentsiya Vladimira Putina [Big Press Conference of Vladimir Putin] (2016). President of Russia, December 23, 2016. Available at: http://www.kremlin.ru/events/president/news/53573,

Cohen S. (1973) Folk Devils and Moral Panics: The Creation of the Mods and Rockers, St. Albans: Paladin.

Demyankov V.Z. (2017) Transfer znanij i kognitivnaya manipulyatsiya [Knowledge Transfer and Cognitive Manipulation]. Voprosy kognitivnoj lingvistiki, no 4, pp. 5-13.

Edelman M. (2007) Konstruirovanie sotsial'nykh problem kak chast' politicheskogo spektaklya [Constructing Social Problems as Part of Political Play]. Sotsial'nye problemy: konstruktsionistskoe prochtenie. Khrestomatiya [Social Problems: Constructionist Reading. Reader], Kazan: Publishing house of Kazan University, pp. 185-196.

FAS: Zapret prodazhi alkogolya dlya IP mozhet «ubit'» malyj biznes v ehtoj sfere [FAS: Prohibition of Alcohol Sales by IP Threatens 'Killing' Small Business in the Area] (2016). Moskva. Agentstvo gorodskikh novostej, November 23, 2016. Available at: https://mskagency.ru/materials/2610835, accessed 15.05.2019.

Gmel G., Klingemann S., Müller R., Brenner D. (2001) Revising the Preventive Paradox: The Swiss Case. Addiction, no 96,pp. 273-284. DOI: 10.1046/j.1360-0443.2001.96227311.x

Gubit lyudej ne pivo? [Is It Not Beer that Kills People?] (2017). VCIOM, August 16, 2017, no 3442. Available at: https://wciom.ru/index.php?id=236\&uid=116356, accessed 15.05.2019.

Hilgartner S., Bosk Ch.L. (2007) Rost i upadok sotsial'nykh problem: kontseptsiya publichnykh aren [The Rise and Fall of Social Problems: the Concept of Public Arenas]. Sotsial'nye problemy: konstruktsionistskoe prochtenie. Khrestomatiya [Social Problems: Constructionist Reading. Reader], Kazan: Publishing house of Kazan University, pp. 145-184.

Ibarra P., Kitsuse J. (2007) Diskurs vydvizheniya utverzhdenij-trebovanij i prostorechnye resursy [Claims-making Discourse and Vernacular Resources]. Sotsial'nye problemy: konstruktsionistskoe prochtenie. Khrestomatiya [Social Problems: Constructionist Reading. Reader], Kazan: Publishing house of Kazan University, pp. 55-114.

Kazun A.D., Kazun A.P. (2017) Kogda beda prikhodit ne odna: osveshchenie trekh tragedij v rossijskih SMI [When Troubles Never Come Alone: The Coverage of Three Tragedies in the Russian Media]. Monitoring obshchestvennogo mneniya, no 3, pp. 128-146. DOI: 10.14515/monitoring.2017.3.09

Kolosnitsyna M.G., Khorkina N.A., Sitdikov M.T. (2017) Ogranicheniya torgovli i potreblenie alkogolya: o rezul'tativnosti gosudarstvennoj politiki [Restrictions on Trade and Alcohol 
Consumption: on the Effectiveness of Public Policy]. Problemy prognozirovaniya, no 5, pp. 116-128.

Kolosnitsyna M.G., Khorkina N.A., Volkov A.Yu. (2018) Vneshnie effekty potrebleniya alkogolya: vliyanie mer antialkogol'noj politiki na prestupnost' [External Effects of Alcohol Consumption: the Impact of Anti-Alcohol Policy Measures on Crime]. Voprosy ekonomiki, no 3, pp. 130-152.

Kreitman N. (1986) Alchohol Consumption and the Preventive Paradox. British Journal of Addiction, vol. 81, no 3, pp. 353-363. DOI: 10.1111/j.1360-0443.1986.tb00342.x

Lazarsfeld P., Merton R. (2002) Massovaya kommunikatsiya, massovye vkusy i organizovannoe sotsial'noe dejstvie [Mass Communication, Popular Taste and Organized Social Action]. Massovaya kommunikatsiya $v$ sovremennom mire: metodologiya analiza i praktika issledovanij. Khrestomatiya [Mass Communication in the Modern World: the Methodology of Analysis and the Practice of Research. Reader], Moscow: Editorial URSS, pp. 139-150.

Matveichev O. A. (2016) Informatsionnye vojny XXI veka. "Myagkaya sila» protiv atomnoj bomby [Information Wars of the XXI Century. "Soft Power" against the Atomic Bomb], Moscow: The Book World.

Meylakhs P. (2004) Diskurs pressy i press diskursa: konstruirovanie problemy narkotikov v peterburgskikh SMI [The Discourse of Press and the Pressure of Discourse: Designing the Problem of Drugs in St Petersburg Media]. Zhurnal sotsiologii i sotsial'noj antropologii, no 4, pp. 135-151.

Nemtsov A.V. (2018) Smerti pri otravlenii alkogolem v yanvare v Rossii (2004-2016 gg.) [Deaths from Alcohol Poisoning in January in Russia (2004-2016)]. Voprosy narkologii, no 2, pp. 155-167.

O realizatsii postanovleniya po ogranicheniyu realizatsii spirtosoderzhashchej nepishchevoj produktsii [On the Implementation of the Resolution on the Restriction of Sale of Non-drinking Alcohol] (2017). Federal Service for Surveillance on Consumer Rights Protection and Human Wellbeing, January 22, 2017. Available at: http://rospotrebnadzor.ru/about/info/news/news_details.php?ELEMENT_ID=7713 \&sphrase $\mathrm{id}=1385249$, accessed 15.05.2019.

Otravlenie v Irkutske Onishchenko nazval splanirovannym ubijstvom lyudej [Onishchenko Calls Poisoning in Irkutsk a Planned Killing of People] (2016). Govorit Moskva, December 19, 2016. Available at: https://govoritmoskva.ru/news/103519/, accessed 15.05.2019.

Radaev V. (2017) A Crooked Mirror. The Evolution of Illegal Alcohol Markets in Russia since the Late Socialist Period. The Architecture of Illegal Markets: Towards an Economic Sociology of Illegality in the Economy (eds. Beckert J., Dewey M.), Oxford: Oxford University Press, pp. 218-241.

Radaev V.V. (2017) Doklad na panel'noj sessii «Nelegal'nyj rynok alkogolya: preuvelichenie ili opasnaya real'nost'?». Forum «Alkogol'nyj rynok: ot zapretov k razvitiyu» [Plenary Talk at the Plenary Session “The Illegal Market of Alcohol: Exaggeration or Dangerous Reality?”]. Moscow, September 22, 2017. Available at: https://profibeer.ru/video/30687/, accessed 15.05.2019.

Radaev V. (2018) The Kingdom of Curved Mirrors: The Evolution of Unregistered Alcohol Markets in Russia in the 1980s-2010s [The Kingdom of Crooked Mirrors: the Evolution of Illegal Alcohol Markets in Russia from the 1980s]. Mir Rossii, vol. 27, no 3, pp. 28-60. DOI: 10.17323/1811-038X-2018-27-3-28-60

Rasporyazhenie Pravitel'stva RF ot 30 dekabrya 2009 g. N 2128-r «O Kontseptsii realizatsii gosudarstvennoj politiki po snizheniyu masshtabov zloupotrebleniya alkogol'noj produktsiej i profilaktike alkogolizma sredi naseleniya RF na period do 2020 g.» [The Concept of the Implementation of the State Policy to Reduce the Scale of Alcohol Abuse and Prevention of Alcoholism in the Population of the Russian Federation for the Period until 2020] (2009). Available at: https://base.garant.ru/12172220/, accessed 15.05.2019.

Skog O.-J. (1999) The Prevention Paradox Revisited. Addiction, vol. 94, no 5, pp. 751-757.

Skorobogatov A. S. (2016) Vliyanie politiki ogranicheniya nochnoj prodazhi krepkogo alkogolya na potreblenie i zloupotreblenie alkogolem v Rossii [The Impact of the Policy Limiting the Night Sale of Alcohol on the Consumption and Alcohol Abuse in Russia]. Journal of Institutional Studies, vol. 8, no 3, pp. 72-90. 
Spector M., Kitsuse J. (1998) Konstruirovanie sotsial'nykh problem. Konteksty sovremennosti. Khrestomatiya [Contexts of Our Time. Reader], Kazan: ABAK, pp. 75-78.

Upotreblenie alkogolya [Alcohol Consumption] (2017). Levada-Centre, May 18, 2017. Available at: https://www.levada.ru/2017/05/18/upotreblenie-alkogolya/, accessed 15.05.2019.

Yasaveev I.G. (2004) Konstruirovanie sotsial'nykh problem sredstvami massovoj kommunikatsii [The Construction of Social Problems by Means of Mass Communication], Kazan: Publishing house of Kazan University.

Yasaveev I.G. (2007) Konstruirovanie «ne-problem»: strategii deproblematizatsii situatsij [Designing the 'Non-problems': the Strategy of Deproblematization of Situations]. Sotsial'nye problemy: konstruktsionistskoe prochtenie. Khrestomatiya [Social Problems: Constructionist Reading. Reader], Kazan: Publishing house of Kazan University, pp. 255-275. 